\title{
A Historical Analysis of the Interconnectivity of Ogun Onire Festival and Ire-Ekiti: Tracing the Ancestral Link
}

\author{
Adeleye, Oluwafunke Adeola
}

\author{
Department of History and International Studies \\ Ekiti State University, Ado-Ekiti. \\ 08067172929 \\ deolaleye@gmail.com
}

\begin{abstract}
Ogun is a prominent god in Yoruba traditional religious belief. He is renowned and might not require the introduction needed for some other deities in Yorubaland. This study examines the migration account of the origin of the people of Ire-Ekiti, belief about Supreme Being (God) who is worshipped through gods in Yorubaland prior to the coming of the Europeans and the indigenous culture in Ire-Ekiti before the advent of Western Culture. The study focuses principally on the form of Ogun that does not enjoy prominence, which represent a deviation from its other forms in Yorubaland. The focus of this study is to assess the heroic deeds of Ogun, the deity on the evolution of Ire community in Ekiti State. The study examines the circumstances culminating in the emergence of the celebration of Ogun, a deity in Yorubaland. Though Ogun is peculiar to the Yoruba race, he will be discussed majorly within the boundaries of Ire-Ekiti. The study makes use of historical analysis to achieve its objectives. To attain this, primary and secondary sources were used. Primary sources include interview, praise poems, cognomen and rituals. The secondary sources include written materials e.g. journals, textbooks, newspapers, monographs and internet materials.
\end{abstract}

Keywords: Festival, Ogun, Ire Ekiti, Yoruba deities, Culture

\section{Introduction}

Festivals are celebrated to preserve the cultural heritage of the society. As a socio-cultural phenomenon, festivals are connected with various deities like Osun, Ifa, Sango, Obatala among others to preserve their heroic deeds and attributes and as means of venerating them (Olajubu, 1982). Festivals in Yorubaland represent auspicious occasions when people celebrate religious, social, political and cultural events. Indeed, in Ire Ekiti, Ogun Onire festival is celebrated annually to commemorate Ogun - the Yoruba god of war and heroism. Ogun, god of iron, technology, war, roads and creativity stands for bravery and justice (Adeniyi, 1987; Faluyi, 2017). Ogun is the guardian of the truth, the defender of the poor, the oppressed and the downtrodden (Miraj, n.d). He is the patron of the guild of hunters, warriors, road users and all those who work with iron equipment. Ogun holds a pride of place among farmers and hunters in Yorubaland (Oguntuyi, 1979). Ogun is widely known and celebrated 
across Yorubaland. Only two other gods enjoy similar patronage as Ogun. The first is Ifa, god of divinity and the second is Esu, the god who delivers sacrifices and offerings to the targeted god (Barnes, 1997). Ogun festival is celebrated by every class in Yorubaland. Hence the saying “t'eru t'omo ni n b'Ogun”, meaning - both slaves and freeborn celebrate Ogun festival.

In Yoruba mythology; Ogun is referred to as "Oshin Imole" - the leader of the deities because he led the other deities to earth. This is the reason he is frequently referred to as "Olulana" and given this superior position among deities, he eats first during sacrifices especially in blood offerings, since the knife or cutlass is made of iron (Faluyi, 2017). Thus, Ogun remains the leader and pathfinder of other deities which include but are not limited to Osun, Oya, Ifa, Obatala, Osanyin, Sango, Yemoja, as he is acclaimed to have cleared the path, being a warrior and a blacksmith, and led the deities to earth. In affirming this and reiterating the heroic deeds of Ogun, Ofeimun (2003) states:

whether from the standpoint of a creation myth in which Ogun is the path-maker who cleared the way from the gods to humankind, or the entrepreneur who produced the fire of civilization to lift humanity from barbarism, or the war-monger who protects the weak but could also devour them in sheer gore-mongering... Ogun had become a twentieth Century deity, who superintended not only over iron foundries that gave rise to modern civilization but other scientific pursuits, beyond metallurgy, in electricity, electronics and related feats.

O. Ogundola (personal communication, June 10, 2018) affirms that Ogun, who is often erroneously believed to be a descendant of Oduduwa and given birth to in Ile-Ife, was a foreigner who journeyed to Yorubaland. His father's name was Tabutu; his mother's name was Orororiran and he is said to have lived around 1383-1475 AD (Tinuoye, 2010). Ogun during his lifetime was a skilled and renowned warrior, craftsman, hunter, blacksmith and medicine man who has passion for war and was always ready for war. He was more than skilled and renowned at war; he was an enthusiastic warlord, who delighted in war. Odu Ogunda Meji, an Ifa verse buttressed Ogun's tenacity and preparedness for war. It states that: 
Ile nimoti jade wa

Ona mi nimo $\mathrm{n}$ to

A dia fun Ogun Ejemu Oluwonron

Adigirigiri re bi ija.

Ogun was deified after his demise and he is presently being worshipped in the Yoruba nation and beyond, as far as Cuba and Brazil (Tinuoye, 2010). The importance of Ogun and the role he played in the history of Ire-Ekiti caused the people of Ire-Ekiti to immortalize him. His outstanding performance earned him “Onire.” He became recognized as Ogun Onire meaning Ogun of Ire or Ogun, owner of Ire. Ogun Onire festival is celebrated in Ire-Ekiti annually in the month of August. The benefits of celebrating Ogun Onire include, but are not limited to: promotion of peace, protection from accidents, bountiful harvest, wealth and prosperity, safety and security, among others (Olaleye, 2017).

\section{Historical and Geographical Description of Ire-Ekiti}

Ire-Ekiti is a town in present-day Oye Local Government Area of Ekiti state in southwestern Nigeria. The town is also called Ire m'Ogun because of its connection to Ogun, the Yoruba god of iron. According to Olaleye (2017):

Ire is synonymous with Ogun, one of the traditional deities highly revered by the Yoruba race. Even other tribes like the Benin and Nupe have a high regard for the deity known as 'the god of iron,' being the first person to cast iron into cutlasses and hoes for farming in Yorubaland or any town that so took its origin from the cradle of the Yoruba race, 'Ile Ife'.

The present day Ire-Ekiti has always been unknown with the name and has not always occupied its present location. It used to be known as Oke-Ori or Igbo Irun (Ibigbami, 2011). Ogun, his son, Dahunsi (who had been given the title "Onire" meaning the owner of fortune) and his entire household travelled from Ile-Ife to Igbo Irun. This development is not unlike the widespread trend that runs through migration accounts of the traditions of Origins where newcomers asserted themselves over the aboriginal inhabitants. Usually more sophisticated, full of ambition and greedy for power, they absorbed the inhabitants and established kingdoms (Oguntuyi, 1979). 
Ogun, the newcomer, established dominance on the aborigines and established his son, Dahunsi, the king of Igbo Irun. Igbo Irun, having a king with the title of Onire (owner of ire) while ire means fortune, became known as Ire. Ogun, having established dominance over the kingdom of Ire, departed from them and embarked on military adventure. The Onire and the people of Ire lived contentedly till the outbreak of smallpox epidemic. When the Ifa oracle was consulted as regards the disease, they were instructed to go farther in the eastward direction for better living. They moved eastwards for about four miles and settled in the present site of Ire-Ekiti (Ibigbami, 2011). Ire Ekiti has an approximate population of 26,999. Its neighbours are: to the west - Oye Ekiti $(5.3 \mathrm{~km})$, Afao Ekiti $(5.6 \mathrm{~km})$, Are Ekiti $(6.0 \mathrm{~km})$; to the north - Itapa Ekiti $(4.0 \mathrm{~km})$, Osin Ikole Ekiti $(4.1 \mathrm{~km})$ to the east -Ijesha Isu $(6.3 \mathrm{~km})$, to the south Igbemo $(3.3 \mathrm{~km})$, Ijan $(7.0 \mathrm{~km})$ ("Ire Ekiti”, 2016).

\section{The Political Structure of Ire-Ekiti}

The traditional political system of Ire-Ekiti is monarchical, and there exists a hierarchy of authority from Onire (king) down to the Baale (father of the house). The Onire is a constitutional monarch who performs executive, legislative and judicial functions with the help of his chiefs who represent their various quarters. Succession to the throne of Onire is hereditary. The Onire equally performs religious duties on behalf of the town. The Onire and his Council of Chiefs form the highest governing body in Ire Ekiti (Akinjogbin \& Ayandele, 1980). The headquarters of the administration is the Onire's Aofin (court) where the chiefs converge, in association with the Onire in making decisions for the entire town. Some of the chiefs include Asaba, Ejelu, Oniyein, Eyelaye, Olomodire, Alawe, Ajagio, and Odofin. S. Oguntile (personal communication, November 15, 2017) affirms that the chiefs perform judicial roles in their various quarters and only grave offences were taken to the king. The Olori Ebi (head of the family), usually the oldest male in an extended family controls the affairs of the family and resolves disputes among members of the family. Each Baale (father of the household) exercises administrative power over his household as he deems fit, within the confines of the law.

\section{Social Administration of Ire-Ekiti}

The family remains the first social institution where the Baale (father of the household) is virtually everything to his people. He leads the religious and social functions of his family. 
The town is organized into societies using age-grouping. A person enters the service of the town at about the age of thirteen. Each age group association has its officials and duties to the town. Such duties include, cleaning of the streets, clearing of paths leading to the market, fetching of water, fetching of firewood, digging of graves, assuming the roles of soldiers, punishing public offenders, while the last age group resolves disputes. The guilds of trade like hunters and herbalists perform their various duties in physical and spiritual defence of the town respectively. Though few of these duties did not survive western civilization, others are, however, considerably in practice. O. Fatuki (personal communication, March 12, 2018) confirms that, of the principal quarters that form Ire Ekiti, each possesses its own age group known as:

Age Group

i. Egbe Mojiyankan:

ii. Egbe Egiri:

iii. Egbe Ekoron:

iv. Egbe Esape:

v. Egbe Esa:

vi. Egbe Agba:
Age Range

13 years to 24 years.

25 years to 34 years.

35 years to 44 years.

45 years to 55 years

56 years to 69 years.

70 years upwards.

\section{Origin of Ogun Onire festival}

In Yorubaland, Ogun is found to be the cult which provides the most festive socio-political ritual celebrations of the year (Adegbola 1983). The Ogun Onire festival is celebrated annually in Ire- Ekiti in memory of Ogun. The Origin of Ogun Onire festival is woven around the deeds of Ogun, while he was mortal. Legend maintains it that when Ogun was returning to Ire in search of his people who had moved from their previous settlement, he came across a group of people holding Ujo Oriki (a silent meeting). Since speaking was forbidden at the meeting, they could neither greet Ogun nor acknowledge him. Ogun got angry because he was not spoken to and was not offered palm wine. Ogun unsheathed his sword and massacred many of the people at the meeting (Ibigbami, 2011). When the tragic news of the horrific massacre got to the king Dahunsi, he recognized the perpetrator as his father - Ogun. The king ordered and supervised the preparation of food and drinks for Ogun. 
Ogun realized he had killed his town people when his fury abated. He went back the way he came and met a man who appeased him with roasted yam and palm wine. After he had been appeased, Ogun invited the people and promised to come to their aid whenever he was called upon for help. He taught them how to call him, drove his sword into the ground, crouched on it and was swallowed by the earth at a place called Iju. The man who appeased Ogun became known as Elepe - the one who appeased, and his children after him became the custodian of Iju, never again to behold the king of Ire (Balogun, 2014). In Ire, reputed to be the place of abode of Ogun when he left Ile-Ife and, therefore, the home of his first foundry, the annual Ogun festival celebrates his heroic exploits with his people and his last days among them. When after a senseless slaughter of his people, he vowed to them his protection whenever they call upon him (Tinuoye, 2010). M. Ariyo (personal communication, July 28, 2011) states that the festival is believed to have started during the reign of king AlagbaJujuke. The festival primarily included a legitimate act of war where people who were immune to the effects of iron weapons confronted each other with machetes. The fighting is done in remembrance of Ogun - the great warrior and ancestor of the people of Ire Ekiti.

\section{The differences between Ogun Onire and other brands of Ogun}

Ogun is universally acknowledged as an indispensable god in the Yoruba traditional belief system (Daramola \& Adebayo, 1975; Gleason, 1971). He is regarded as the owner of all iron and steel. Thus, his celebration cuts across all professions. He is also called Olulana (he who secures the road) and road users are also expected to celebrate him. Ogun is, therefore, celebrated everywhere in the Yoruba speaking country whether by individuals or the community at large. Ogain, Lakaaye, Oshinmole, Olulana or whatever name they choose to designate him refers to Ogun. The differences in the various brands of Ogun like Ogun Alara, Ogun Onikola are predominantly seen in their various modes of celebration. It is only Ogun Onire that accepts the sacrifice of a ram from the Onire because a son worships his father with a ram. Ogun Onire is usually the first to be celebrated in the year. This occurs in August every year in Ire-Ekiti. Ogun is thereafter celebrated in other towns. For instance, it is celebrated in the month of September in Ondo and October in Irun Akoko. The celebration of Ogun in other places employs the use of masquerades. And at other times, passers-by are coerced to part with their money with the threat of flogging and/or blue dyeing. The celebration of Ogun 
Onire is more elaborate than others. Carved images of Ogun, his mother and wife and not masquerades are used during the festival since they are no masquerades in Ire Ekiti. An Ijala verse emphasizing the differences goes thus:

\section{Ogun Meje}

Ogun meje l'Ogunun mi

Ogun Alara ni n gbaja

Ogun Onire a gbagbo

Ogun Onikola ni n gbagbin

Elemona a gbesun isu

Ogun Akirun a gbawo agbo

Gbenagbena eran ahun nii je

Ibe l'Ogun- makinde ti d' Ogun l'eyin Odi.

\section{Translation}

\section{Seven Brands of Ogun}

There are seven brands of Ogun.

Alara's Ogun is given a dog

Onire's Ogun is given a ram

Onikola's Ogun is given a snail

Elemona's Ogun is given roasted yam

Akiirun's Ogun is given the horn of a ram

Gbenagbena's Ogun is given the flesh of a tortoise

Away from home the dance artist presents self as Ogun- the brave traveler himself.

\section{The Connection between Ogun and Onire}

Ogun (god of iron) during his lifetime had a son called Dahunsi who was equally known by the name Onire. Onire became the first king of Ire-Ekiti. Subsequent kings of Ire assumed the title of Onire and in the common parlance, claim they were descended from Ogun. To such a degree, Ogun is believed and regarded as the father of the Onire, starting with the first to the present Onire. This is further confirmed in Odu Idingbe, an Ifa verse which says: 
"Aja, awo Onire lo difa fun Onire

O l'ehoro l'ebo

Agbo, awo Onire lo difa fun Onire

O l'ehoro l'ebo

Akuko, awo Onire lo difa fun Onire

O l'ehoro l'ebo

Ehoro, awo Onire lo difa fun Onire

Nigba ti ko ri iba ile baba re mo

Nje ta lo f'Ogun han Onire?

Ehoro, oun lo f'Ogun han Onire

Ehoro."

\section{$\underline{\text { Translation }}$}

The dog was Onire's divine

Who cast divination for Onire

And told him to sacrifice the hare

The ram was Onire's divine

Who cast divination for Onire

And told him to sacrifice the hare

The cock was Onire's divine

Who cast divination for Onire

And told him to sacrifice the hare

The hare was Onire's divine

Who cast divination for Onire

When his father's blessing on him was waning

Who helped to reconcile Ogun and Onire?

The hare was the one

Who helped to reconcile Ogun and Onire

The phrases in this Ifa Verse which indicate the relationship of Ogun and Onire are:

"The hare was Onire's divine

Who cast divination for Onire 
When his father's blessing on him was waning

Who helped to reconcile Ogun and Onire?

This verse clearly shows that Ogun is the father of Onire. O. Ogundola (Personal communication, June 10, 2018) corroborates this verse that the dog, ram and cock are used as sacrificial items for Ogun because none of them could reconcile him and his son. But this is not the same for the hare who succeeded in the reconciliation attempt between Ogun and Onire. The hare is therefore never sacrificed in the worship or celebration of Ogun Onire festival.

\section{Conclusion}

Ire-Ekiti remains a social and political entity with sectional and central administration for effective governance. Starting from the family, through the quarter to the town as a whole, power and authority increases from each stage to another. The uniqueness of Ire-Ekiti that attracted Ogun and his family to establishes settlement is still present and can be still seen not only in geography, but also in the celebration of Ogun Onire festival. The importance and appreciation of Ogun remain the basis for the celebration of Ogun Onire festival. The festival is directed at celebrating Ogun, the founder of Ire-Ekiti. It is indisputable that Ogun Onire festival is of great importance to the people of Ire-Ekiti and Yoruba culture at large. Ogun Onire pre-dominates other brands of Ogun and as such, must be invoked during the celebration or worship of other brands of Ogun.

\section{References}

Adegbola, A. (1983) Traditional religion in West Africa. Ibadan: Sefer Books Ltd

Adeniyi, D.A. (1987) Ogun ni ile Yoruba. Ibadan: Longman.

Akinjogbin, I.A. \& Ayandele, E. B. (1980) "Yorubaland up to 1800" in Ikime, O. (ed), Groundwork of Nigeria history. Ibadan: Heinemann.

Balogun, W. (2014) Ire-Ekiti: Town where Ogun, Yoruba god of iron, 'disappeared'. Retrieved February 8, 2019 from http://nigeriavillagesquare.com/forum/threads/ireekiti-town-where-ogun-yoruba-god-of-iron-disappeared.85260/

Barnes, S.T. (ed), (1997) Africa's Ogun. Second Expanded Edition: Old World and New. Indiana: Indiana University Press.

Daramola, O. \& Adebayo, J. (1975) Awon asa ati orisa ile Yoruba. Ibadan: Onibonoje. 
Faluyi, B. (2017) Retrieved 7 $7^{\text {th }}$ August, 2018 from http://babalawoweb.com/ogun/@ 2017

Gleason, J. (1971) Orisa: the gods of Yorubaland. New York: Athenaeum press.

Ibigbami, R. I. (2011) "Historical perspective" in Ogun Onire: A tourist guide. Publication of Ire-Ekiti National Congress.

Miraj, P., (n.d.) Retrieved $7^{\text {th }}$ August, 2018 from http://www.watlpad.com/432123291nigerian-tribe-myths-african-ogun

Oguntuyi, A. (1979) History of Ekiti. Ibadan: Bisi Books.

Olajubu, O. (ed) (1982) Iwe asa ibile Yoruba. Ibadan: Longman

Olaleye, A. (2017), September 4, Heritage: At Ogunnire festival, Ire-Ekiti remembers Ogun, god of Iron. Western Post. Retrieved February 8, 2019 from https://westernpostnigeria.com/heritage-at-ogunnire-festival-ire-ekiti-remember3sogun-god-of-iron/amp/

Tinuoye, O.A. (2010) Itan Ogun Onire. Ilorin: Success Talk Publishers.

Ofeimun, O., (2003) In search of Ogun: Soyinka, Nietzche and the Edo Century during The 2003 Egharevba Memorial Lecture. Retrieved November 19, 2018 from http://www.edo-nation.net/eghar6.htm

Ire Ekiti, Nigeria Page (2016). Retrieved September 25, 2018 from http://fallingrain.com/world/NI/54/IreEkiti.html

Odu Idingbe - Ifa Verse

Odu Ogunda Meji - Ifa Verse

Ijala Verse 